\title{
EXPLOITATION AND CATCH FLUCTUATION OF SMALL PELAGIC FISHES IN PRIGI WATERS, SOUTH COAST OF JAVA
}

\author{
Suwarso', Arief Wujdi ${ }^{2}$ and Moh. Fauzi ${ }^{1}$ \\ ${ }^{1}$ Research Institute for Marine Fisheries Jakarta \\ 2 Research Center for Fisheries Management and Fish Conservation \\ Received October 11-2013; Received in revised form December 01-2014; Accepted December 03-2014 \\ E-mail: swarsorimf@gmail.com
}

\begin{abstract}
Studies on the exploitation and catch fluctuations of pelagic fishes have been undertaken in order to understand the fishery systems, annual and seasonal change of fishing effort and catches, as well as species composition. The study was based on the daily monitoring data of the purse seiners. The results showed that generally the fishing activities is one day fishing, the increase of fishing effort reflected in the number of fishing units and the number of trip, while the trend of production and catch rate were fluctuated by either annual or seasonal; the peak of catch rate was occurred in 2007, 2008 and 2012 periods, during December to June were low catches, and are going in the peak season in September-October. The lowest catch rate is about $100 \mathrm{~kg} /$ trip and the maximum of 4.3 tons/trip (the average of 1.3 tons/trip), however the fail of fishing was often occurs and reached $30 \%$ of the total number of trips; the failed fishing was decline from year to year. The catch rate (kg/trip/day) was showed a pattern fluctuations; the small pelagic fish mainly the scads (Decapterus spp.) and clupeids (Bali sardine, Sardinella lemuru), respectively $33 \%$ and $17 \%$, whereas the dominan large pelagic fish is 'tongkol'/frigate tuna (Auxis thazzard). The changes of species domination was occurred either in annually or seasonally
\end{abstract}

\section{KEYWORDS: Exploitation, catch, purse seine, small pelagic fishes, Prigi, South Coast of Java}

\section{INTRODUCTION}

The southern coast of Java waters along 900 nautical miles has a narrow bottom area, steep cliffs, the rocky substrat, sandy and muddy. In the south of Java, the pelagic resources is generally lower than the demersal fish (Venema, 1996), that are more abundance in rainy seasons (Lohmeyer, 1996). The fish schools was detected in the bay area in November (fish season) (Venema, 1996), where those fish resources have a significant role to support the economic life of the community.

The pelagic fish resources around Prigi (Trenggalek District, East Java) caught by using the Mini Purse Seine (local-name 'slérék'), but the other gear such as payang, gill nets, hand line, beach seine are also intensively used. Based on the classification of SEAFDEC (1999) those Prigi's pelagic fisheries is generally categorized as the 'artisanal fisheries' (small scale) with the vessel size between 6-25 GT; one day fishing; fishing areas scattered around the Bay of Prigi to Pacitan and Sendang Biru (Malang). From the total landing of marine fish catch (is about 41000 tonnes in 2011) the catch of small pelagic fish contributed approximately $54 \%$; however, this small pelagic production was reached about $25 \%$ in the 573 Fisheries Management Areas (FMA). The purse seine fishery provided about $88 \%$ with the scads category (Decapterus spp.) was the most common fishes. The others small pelagic fish species is lemuru/Bali

Corresponding author:

Institute for Marine Fisheries Jakarta

Jl. Muara Baru Ujung, Komp. PP Nizam Zachman, Jakarta Utara sardine (Sardinella lemuru), tembang/sardine (Sardinella fimbriata and Sardinella gibbosa), Indian mackerel (Rastrelliger kanagurta), trevally (Selar spp.); the large pelagic fish including tuna (Auxis spp.), Skipjack (Katsuwonus pelamis) and slengseng (Sarda sarda).

The number of purse seine was continuously grow up from year to year, from 70 units in 1996/1997 to 112 units in 2002, and was reached 152 units in 2012. The number of trips was also siginifican increased to 10 times. The increasing of fishing effort make to the complex fishery system so that the proper fishery management is needed in order to maintain the sustainability of the resource. This paper discusses on the pelagic fishing activity, the operational aspects, catch fluctuation, the species dominant and the sharing system in the fishery. The expected results are to obtain the informations of the fish stock abundance as well as to understand the seasonal changes of the resources as a basis for fisheries management and utilization.

\section{MATERIALS AND METHODS}

The study was conducted on the purse seine fishery exists in the Prigi fishing port, Trenggalek district (East Java). The data used in the analyses were the daily monitoring data of the purse seiners landed in Prigi, completed by the information of fishing operational aspects (day at seas, fishing grounds) 
and the number of crews. Monitoring was done on the catch per vessel per species; day at seas and fishing ground was obtained from the report of fishing master recorded in 2012. Catch rate (kg/trip/day) was calculated by dividing the monthly catch yields with the number of trips as follows:

$$
\mathrm{CPUE}=\frac{\text { Catch }(\mathrm{kg})}{\text { Effort (trip) }}
$$

Plotting of the fishing ground was execute through the conversion of GPS data to decimal degree on a work sheet (Microsoft Excel 2007), then the data was processed by using the ArcGIS program ver. 10. Catch and effort fluctuation was shown graphically and in the simple statistic values.

\section{RESULTS AND DISCUSSION}

\section{Result}

\section{Purse Seine Fishery}

Fishing boats and gear

Mini Purse Seine was the main gear for pelagic fishes around Prigi. The wooden vessels were generally ranging from 5 to 22 Gross Tonase (GT), consist of the vessels of $5-10 \mathrm{GT}(54 \%)$, the vessels of $11-20$ GT $(45 \%)$, and a $1 \%$ vessel of 22 GT (2012). The boats length are ranged from 10 to $20 \mathrm{~m}$, the width are 3 to $5.3 \mathrm{~m}$, and the depth are 1 to $1.3 \mathrm{~m}$. Total number of purse seine is 152 units (2012). Those vessels are usually equipped with a main inboard motor (Mitsubishi cylinder 4-6) with the power of 140-160 $\mathrm{hp}$; the two auxiliary engines are also installed as the outboard motor (Yamaha or Suzuki) with the power of 25-40 hp. However, the fishing vessels are also equipped with a potable GPS as a navigation system and a mobile phones for communication.

Purse seine nets ranging from 600 to $700 \mathrm{~m}$ length and $47 \mathrm{~m}$ depth; three kinds of mesh size are consist of 0.75 inches, 1 inch and 2 inches. Basically, the nets are consist of several pieces of rectangular shaped which are made from the polyamide materials (PA). One set of purse seine net is consist of 6 pieces nets with a total length of 570 meters and the 47 meters depth. The body of nets is made from polyamide materials (PA) No. $210 \mathrm{~d} / 6$ with the mesh size of $3 / 4$ inches. However, the upper and lower selvage are made from the PA material No. $210 \mathrm{~d} / 24$ and mesh size of $3 / 4$ to 1 inch. The construction of Prigi's purse seine is presents in Annex 1 .

\section{Operasional Aspects}

Daily fishing operations of purse seine are generally conducted at night without using the lamps. Number of crews ranged between 20 to 25 peoples per trip per vessel, but it will be more people during the fishing season due to the presence of the "ngadim" fishermen (temporary fisherman). Fishing areas scattered around the Bay of Prigi to Pacitan and Sendang Biru (Malang) (Fig. 2). A captain was stay on the higher bridge so that the captain can clearly scan the fish schooling.

Fishing can be classified as two boat system seiners, the first fleet is the catcher, it was serve as carrying the nets and crews, while the second one for towing rope and as a fish haul (carrier) (Fig. 1). In the west season the fishermen applied the technique "ngoncor", i.e. fishing tactic using the lamps as a collecting fish tools. Each vessel carry a small boat (called "pelak") which is equipped with 4 pieces of Mercury lamps with the power 600 Watt each. In the transitional and the east season generally the fishermen do the hunting system through pursue the fish schools directly. Fishing master (a captain) will be observe the fish schools by using the flashes of light and will be setting immadiatelly when the fish schools is found; hauling the nets is done manually by the people. In a every fishing trip the fisherman usually done 2-4 times setting/hauling.

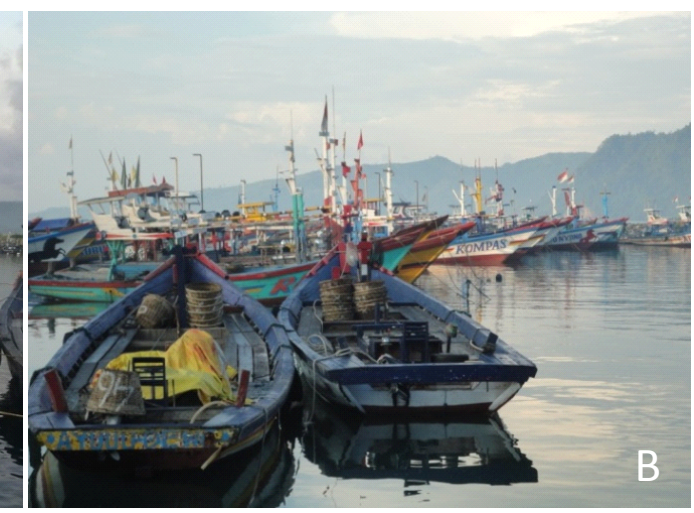

Figure 1. Two boat system of purse seine fishery in Prigi (East Jawa); $(A)$ the catcher; $(B)$ the carrier. 


\section{Fishing Grounds}

The fishing areas is in the waters of Indian Ocean, is distribute from around Prigi bay to westward of Pacitan waters, and eastward around Sempu island. Fishing patterns tend to vary seasonally; in the west monsoon season (December-February) tend to spread
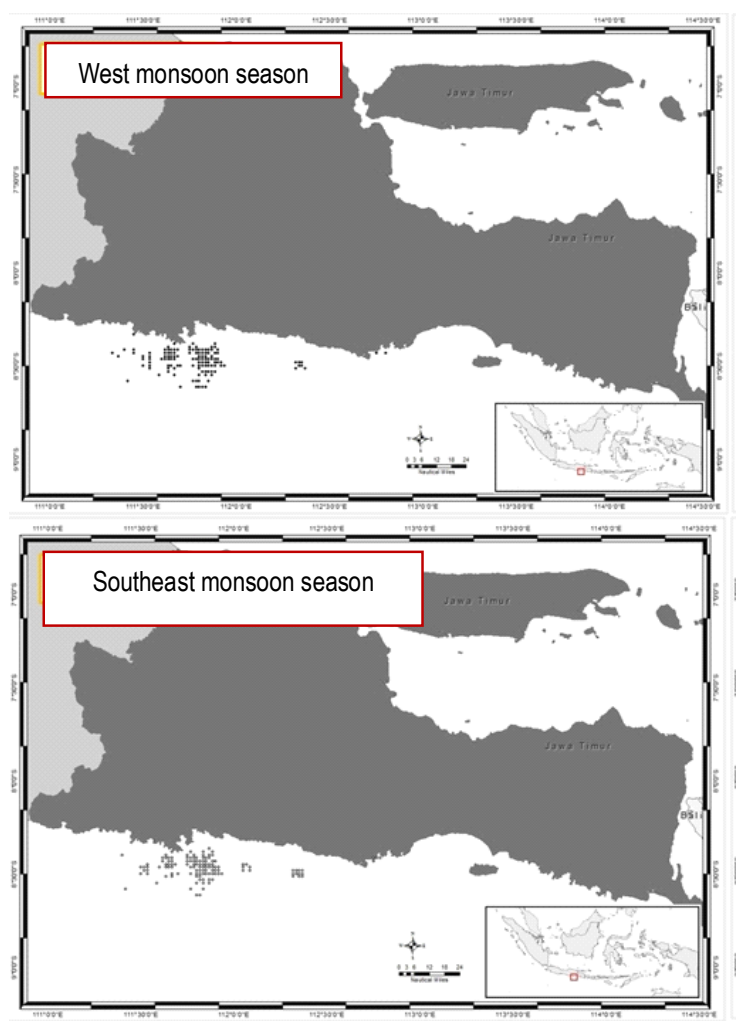

Figure 2. Distribution of purse seine fishing ground around Prigi, 2012.

\section{Catch and Effort}

Number of purse seine (units) was growing continuously over the period of 1999 to 2012 , but it significantly was occured since 2009 (150 units); in addition, number of gear was 157 units in 2010, 159 units in 2011, and 152 units in 2012 (Fig. 3A). During the period 1999 to 2001 Hariati \& Wahyu (2004) had reported that the increase of purse seine from about 69 units in 1996 to 105 units in 2001/2002. The daily monitoring during 2005 to 2012 periods listed that the increasing effort are also seen in the total trips and the number of trips per vessel (Fig. 3B). Monthly fluctuation of the trips is shown in Fig. 4. Fig. 4 presents the lower trips was occured during January and May, the increasing efforts began in June and reached the peak in October; and fishing effort so decrease in December.

The increase of effort not always provided meaningful increase in fish production like fishing in general. Fig. 5A presents the pelagic fish production from west to the east, in the first intermonsoon (March to May) the fishing grounds spread to the southern part waters off the coastal areas; whereas in the southeast monsoon tend to be concentrated around the bay of Prigi and is relatively close. The fishing ground of purse seine is shown in Fig. 2.

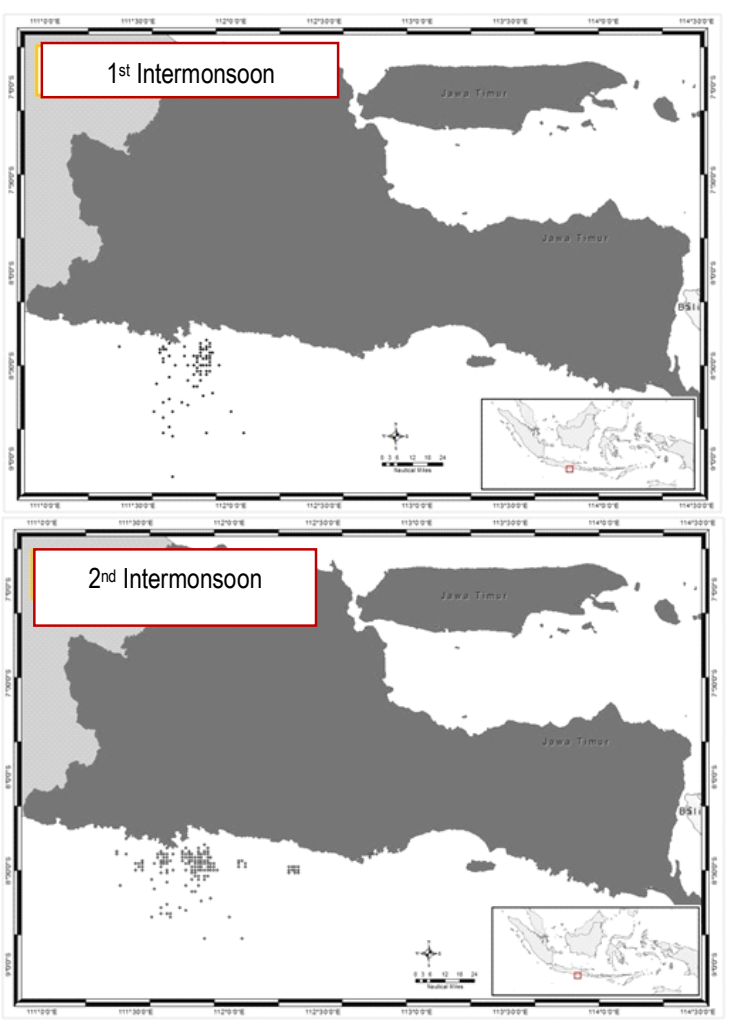

(in tonnes) was really appears to be illustrates the annual patterns of fluctuation. Fish production begin to increase in 2001 and peaked in 2003, but decreasing production was occurred in next year (2004) and reached the minimum in 2005; in 2006 the production increase again and reached the peak production in 2008 followed by a decrease in 2009 and reached a minimum in 2010; the production increased again in 2011-2012. The same pattern was also seen in the catch per unit of effort fluctuations (tons/unit) (Fig. $5 B)$.

Those increasing number of trips was really derived from the both successful fishing (with the fish catch) and unsuccessful fishing (with no catch). Average of unsuccessful trips was reached $30 \%$ during 20052012 , but was tend to be less from year to year, was about $40 \%$ unsuccessful trips in 2005 decrease to $25 \%$ in 2012. However, number of unsuccessful trips was also varies seasonally. Number of unsuccessful trips mainly happened in February to June. Changes in the number of unsuccessful trips seasonally is shown in Fig. 6. 


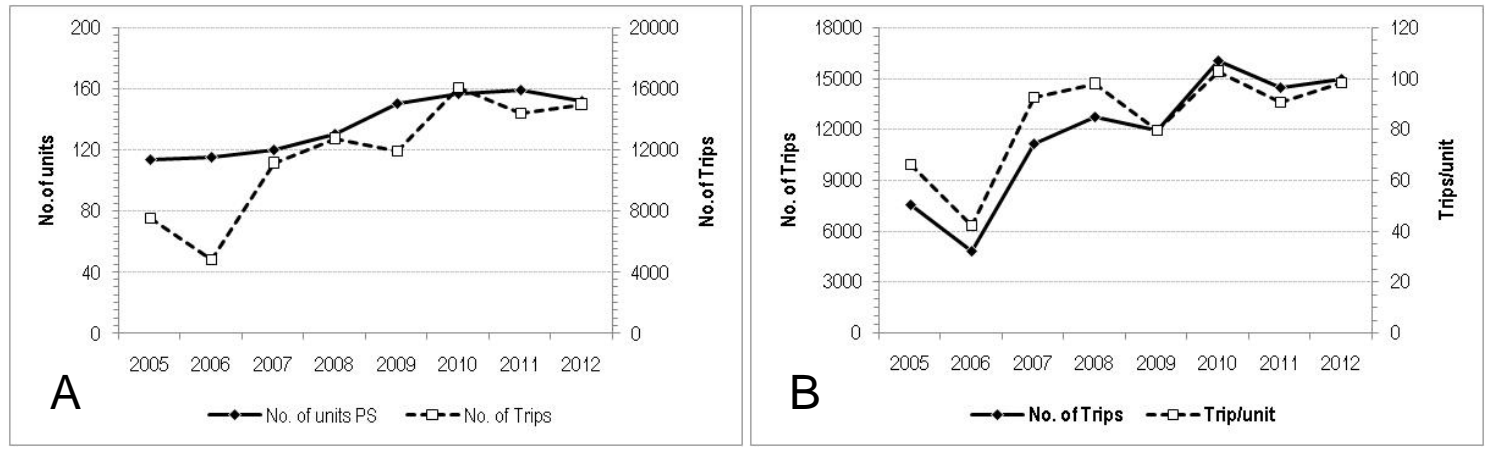

Figure 3. Increasing fishing efforts (number of unit and total trips) of purse seine in Prigi (Trenggalek) during 1999-2012.

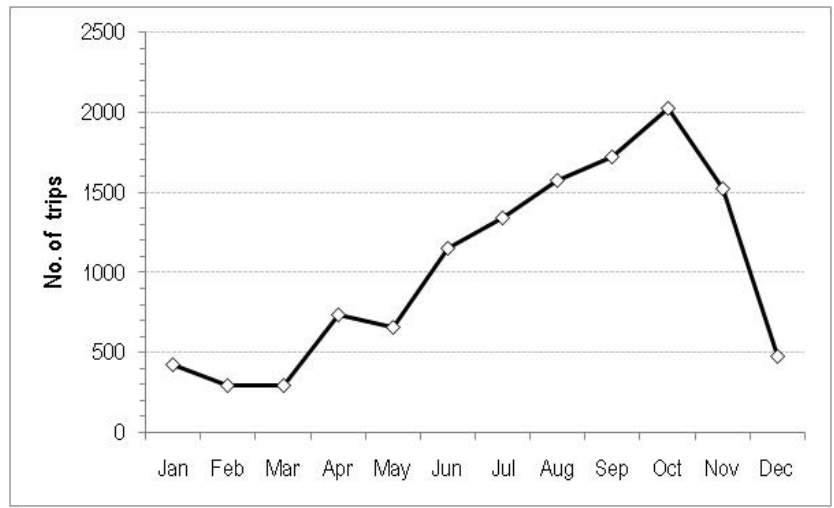

Figure 4. Monthly changes of number of trips (average) of purse seine in Prigi, 2005-2012.

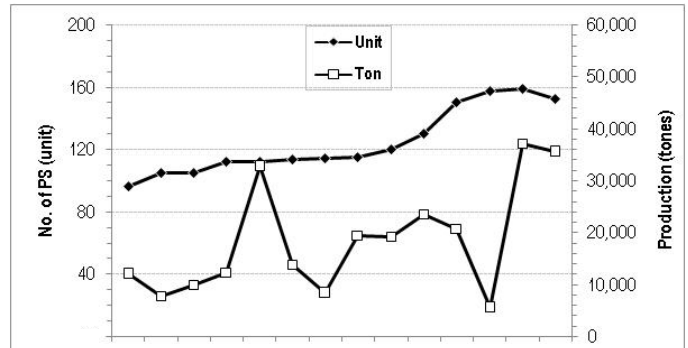

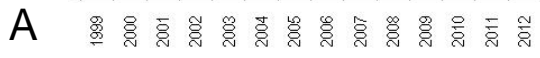

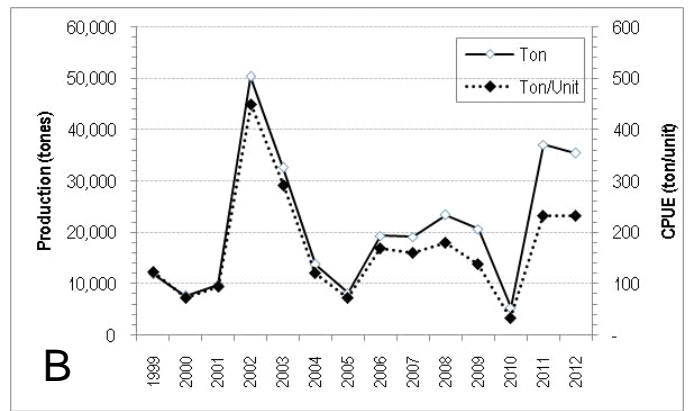

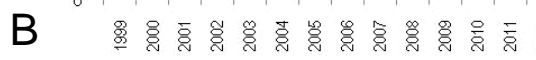

Figure 5. Trend of annual production (ton), effort (unit) and catch per unit of effort (ton/unit) of purse seine in Prigi, 1999-2012.
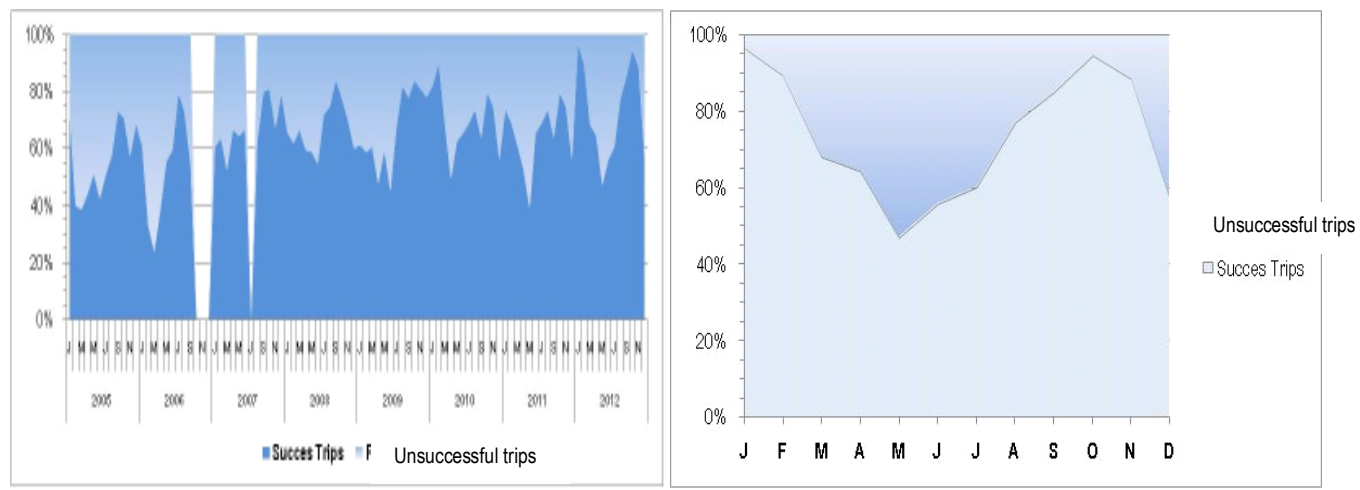

Figure 6. Seasonal changes of number of failed trip of purse seine in Prigi, 2005 to 2012. 


\section{Catch Fluctuation and Species Composition Catch Fluctuation}

Based on the daily catch monitoring during 20052012 periods shown the catch rate $(\mathrm{kg} /$ trip) fluctuates either annually or seasonally. Catch rate as the index of abundance is highly fluctuate between $100 \mathrm{~kg} /$ trip (minimum catch) to 4.3 tons/trip (maximum), the average of catch rate was about 1.3 tons/trip; however,

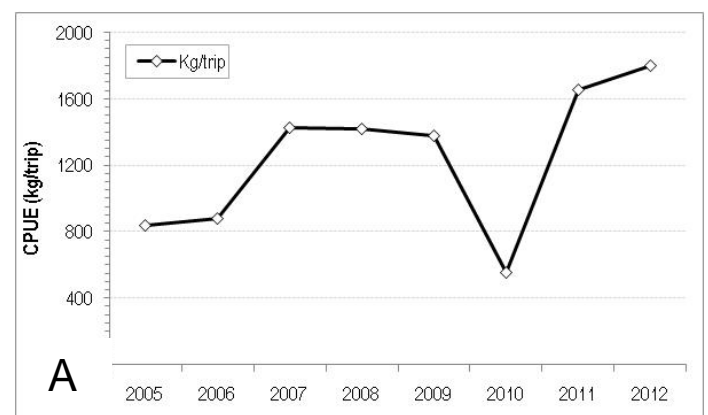

the unsuccessful fishing may reached $30 \%$ of the total trips. Annual fluctuations of the catch rate shows the lower catch rate in 2005-2006 and 2010, while the higher catch rate was occured between 2007-2009 and 2011-2012 (Fig. 7A). Based on the monthly catch rate the abundance fluctuations shows a clear changes seasonally, the lower abundance was occurred during January to July and the peak season occurred on October (Fig. 7B).

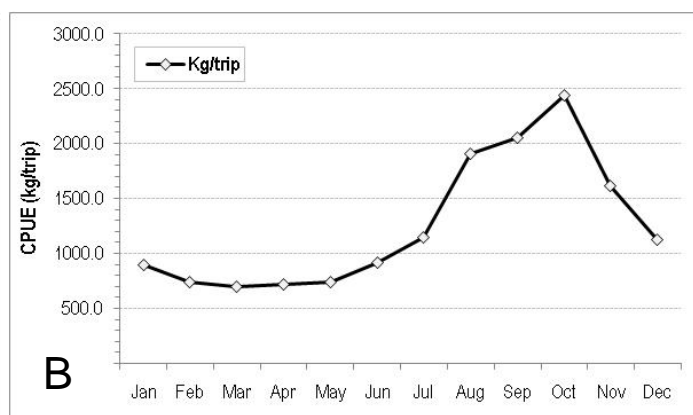

Figure 7. Annual catch rate fluctuation (index of abundance, $\mathrm{kg} / \mathrm{trip}$ ) (A) and seasonal pattern (B) of purse seine in Prigi, 2005-2012.

\section{Species Composition}

Ikan layang/scads (Decapterus spp.), lemuru/Bali sardine (Sardinella lemuru) and tongkol/frigate tuna (Auxis thazzard) are the three main species caught by purse seine around Prigi, which contribute of $33 \%$, $17 \%$ and $44 \%$ respectively to the total catch. Other species caught include slengseng (chub mackerel), cakalang (skipjack tuna), tembang (sardine), trevallies, yellow-fin tuna and other also caught. At least four species of scads was found, such as malalugis $(D$. macarellus), short-fin scads (D. macrosoma), round scads ( $D$. russelli) and red-tail scads/layang anggur (D. kurroides). The annual and seasonal changes of

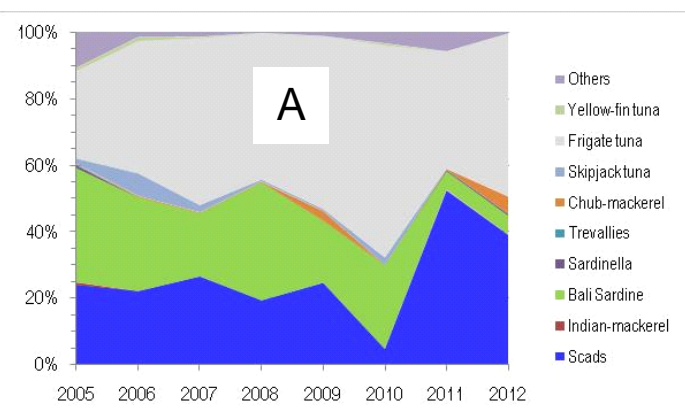

species composition during 2005-2012 shows in Fig. 8 where of percentage of scads declined in 2010, but increased in 2011-2012, but lemuru seem to be lower. The dominance of scads on the catch was higher in August to December; while, contribution of lemuru catch mainly seen on January to May, and tend to be a lower catch on the peak season (August-November). In addition, beside the scads, the 'tongkol'category is generally dominant in the catch all the year and the season. However, the more catch of slengseng (chub-mackerel) was occurred in 2009 and 2012 and between November to December when the fewer catch of tongkol.

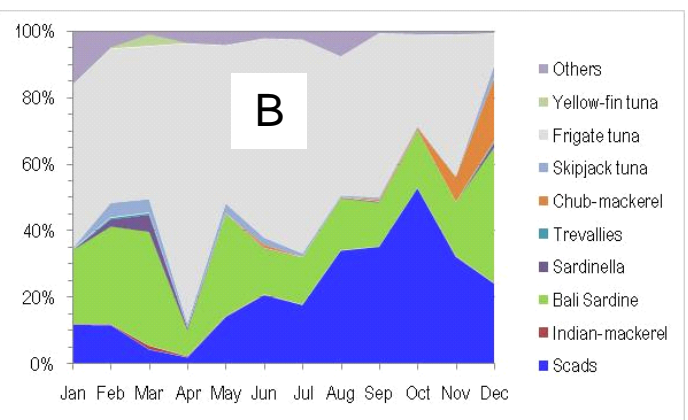

Figure 8. Annual (A) and seasonal (B) changes of species composition in purse seiner's catch in Prigi, 2005-2012.

\section{Sharing System Scheme}

The sales results of MPS catch in one month is called gross income collected by the ship owner. Gross income is then reduced with the operational costs such as the cost of fuel (diesel, gasoline and oil) and fresh water, the cost of repair nets, boats and machinery. The percentage accepted of the crews is $1 / 3$ part $(33.3 \%)$, while the ship owner have $2 / 3$ parts $(66.7 \%)$. This percentage included in the crews was the fishing crew (1 part), captain (1.5 part); fishing master (1.5 part); divers (1.25 part); engine section 
(1.25 part); mason (1.25 part); towing the rope (1.25 parts), and the cleaner fishhold of 4 persons is 1 part each. The captain and fishing master had the additional salary about $10 \%$ of the net income of the ship owner; the drain fishhold get the additional services about $10 \%$ of gross catches. Details of this sales results of the catch are unlikely to have the standard forms and fixed. The percentage belonging to the crew section usually take the catch at first before it catches were weighted, which have the amount varies between $10-35 \mathrm{~kg} /$ person. Illustration of the catch revenue of purse seine in Prigi described in Fig. 9.

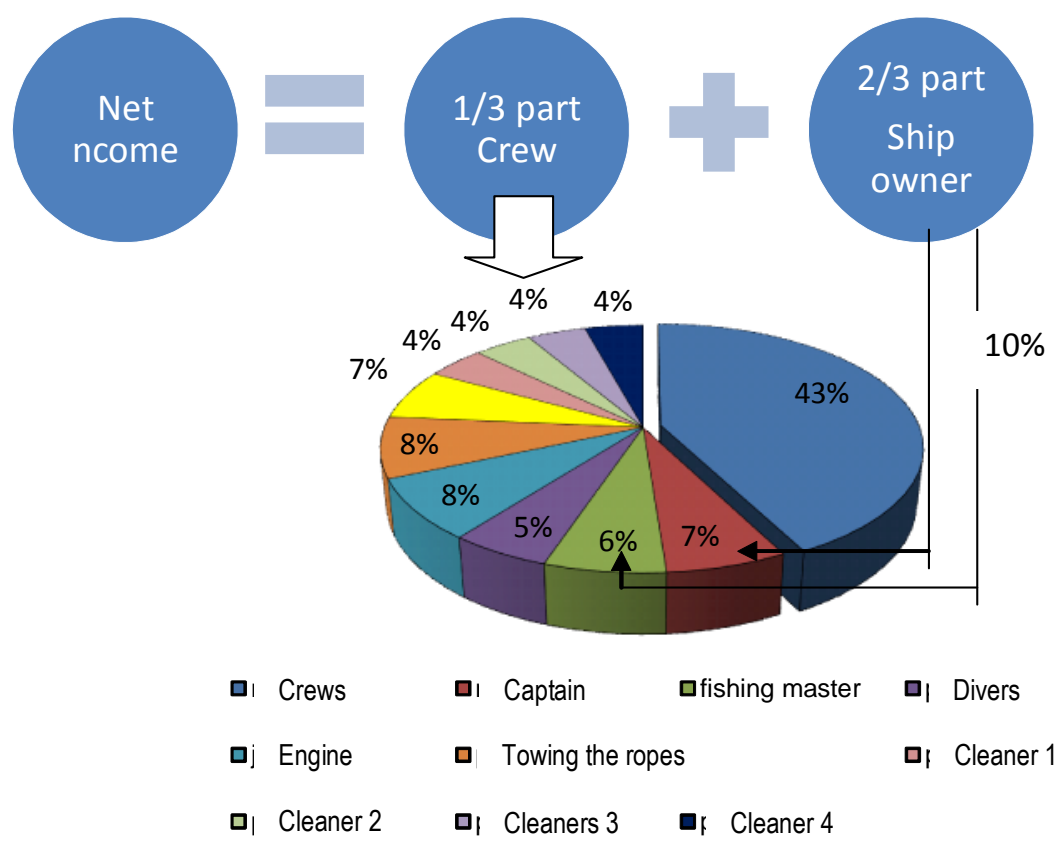

Figure 9. Sharing system scheme of purse seine catch in Prigi.

\section{Discussion}

Prigi's purse seine fishery is artisanal fishery that are small scale with the fishing grounds limited in the coastal zone around Prigi, usually one day fishing along with fish hunting. The depth of the nets is only reach $45 \mathrm{~m}$ depth may related to the distribution of pelagic fish stocks, oceanographic conditions and the fishing strategy; this strategy its different with the depth net use by the fishermen in other waters; in Java Sea the fishermen usually use the depth net of $60 \mathrm{~cm}$.

Although it is such a small scale fishery, however the increasing of the fishing effort was occurred from year to year, both in terms of increasing the number of vessels/gear and the number of trips. It was not significant increase of the production and catch rate of the pelagic fish, its catch were seen fluctuate on the annual basis (probably follow the pattern of the annual cycle fluctuations). Significant fluctuations are indicated by the seasonal pattern of the fishing activity (number of trips), catch rates (abundance) as well as the changes in species dominance. The fishing activities are generally lower between December and July with also the lower catch, continuing the fishing season in August to November; the peak season occures on September-October. Number of failed trips were reached about $30 \%$ of the total trips where are usually found in March to August (peak in May) was confirmed the condition of fish stocks when it is possible related to the condition of the oceanographic condition. Improving capacity in the fishing techniques may reduced the failed trips over the years.

Species composition was varies yearly and seasonally. Scads, lemuru and tongkol are the three main species caught by the purse seine Prigi mainly in the fish season (August to November) each contributing $33 \%, 17 \%$ and $44 \%$. Two species of scads that is malalugis and round scads are the oceanic species that is commonly found, however the round scads are the coastal. According to Hariati \& Wahyu (2004) there may be two species of red tail scads, namely $D$. kurroides and $D$. tabl. The four species of scads are including in the monitoring data such as the scads category. Changes in the species composition were related to changes in the oceanographic condition. The same thing was happened in other waters such as the Java Sea (Potier \& Sadhotomo, 1995) and the South China Sea (Wudianto et al., 2007) where the ikan layang/scads 
as a main component of catch is very dominant at the peak season (September to November).

Crews conditions in the purse seine fishery is unique because this economic system can be affect the total catches recorded due to the social relationship between the crew with the ship owner. Number of crew normally between 20-25 people per boat per trip but the more crews could be rise more than 30 people during fishing season. Due to the reward of more crews were not recorded, those indicate the total recorded catches was fewer than that of the actual catch; of cource, this may caused the total production of the fishing area (FMA 573).

\section{CONCLUSIONS}

1) Purse seine fishery in Prigi is the small-scale artisanal fishery which the activity is daily (one day fishing) and hunting tactics.. Fishing grounds scattered in the limited zones of coastal waters around Prigi, the Indian Ocean. More crews over the fishing season and fish season may increase the unreported catch in Prigi and can affect the total production of the fishing area.

2) Increasing fishing effort does not related to the annual increase production, but the fish production fluctuates according to a certain pattern (annual cycle). Seasonal fluctuations of the fishing activity (number of trips), catch rates (abundance) and species dominance significantly estimate related to the oceanographic condition. In December and July the fishing activity and catch rates are generally low, increasing of the catch rate start in August and reach to the peak season in September-October. Number of failed trips approximately reach $30 \%$ of the total trip, especially was occurred during March to August, but now this failed trips were fewer.

3) Species composition is varies annually and seasonally. Scads, lemuru and tongkol are the three main species in purse seine catches, especially in the fishing season, each contributing $33 \%, 17 \%$ and $44 \%$ of the catch.

\section{ACKNOWLEDGEMENT}

This paper was part of the results of research on the stock, distribution and biology parameters of small pelagic fish for supporting fisheries industrialization on the WPP 572, WPP 573 and WPP 717, Fiscal year 2013 at Research Institute for Marine Fisheries, Muara Baru-Jakarta. The author wish to thank to the Director of Research Institute for Marine Fisheries (BPPL) for giving the chance to be involve in this research. The auothor also wish to thank to the technicians (Adi Kuswoyo, Hari Ilhamdi and Fadli Yahya) for helping in data collection and compilation.

\section{REFFERENCES}

Anonimous. 2001. A review of Indonesia's Indian Ocean Tuna fisheries. ACIAR, CSIRO, RIMF, BAV Country Status Report: 106p.

Hariati, T \& I. S. Wahyuni. 2004. Penangkapan ikan dengan alat sleret di perairan Prigi. Warta Penelitian Perikanan Indonesia, Edisi Sumber Daya dan Penangkapan, 10(6): 12-16.

Hariati, T. 2003. Ikan layang ekor merah. Warta Penelitian Perikanan Indonesia, Edisi Sumber Daya danP enangkapan, 9(7): 6-9

Hariati, T. 2005. Ikan Layang Biru, Ikan Pelagis Kecil laut dalam. Warta Penelitian Perikanan Indonesia, Edisi Sumber Daya dan Penangkapan, 11(5): 1518.

Hariati T. 2005. Aspek Perikanan Pelagis Kecil dan Biologi Ikan Layang Deles. Warta Penelitian Perikanan Indonesia, Edisi Sumber Daya dan Penangkapan, 11(5): 18-22.

Lohmeyer, U. 1996. Narrative and major results of the Indonesian-German Module (II) of the Jetindofish Project, August 1979 - July 1981.In: Dr. D. Pauly\& Dr. P. Martosubroto (eds.). Basedline studies of Bio-diversity: The fishes resources of Western Indonesia. DGF-Indonesia, GATS and ICLARM: $p$. 77-90.

Potier, M \& B. Sadhotomo. 1996. Exploitation of the large and medium seiners fisheries in the Java Sea. Eds.: Potier, M. and S. Nurhakim. BIODYNEX. Java Sea Pelagic Fishery Assessment Project.

Venema, S. C. 1996. Result of surveys for pelagic resources in Indonesian waters with the R/V Lemuru. December 1972-May 1976.In: D. Pauly\& P. Martosubroto (eds.). Baseline studies of Biodiversity: The fishes resources of Western Indonesia. DGF Indonesia, GATS Germany, and ICLARM Philippines. P. 102-122.

Wudianto, Suwarso \& T. Hariati. 2007. Fishery and biological information of small pelagic fishes in the South China Sea of Indonesia. Report of the Fourth Regional Technical Consultation Meeting On Information Collection for Sustainable Pelagic Fisheries in the South China Sea. 
Ind.Fish.Res.J. Vol.20 No.2 December 2014: 69-76

\section{Annex 1. Construction of mini purse seine in Prigi, Trenggalek, East Java}

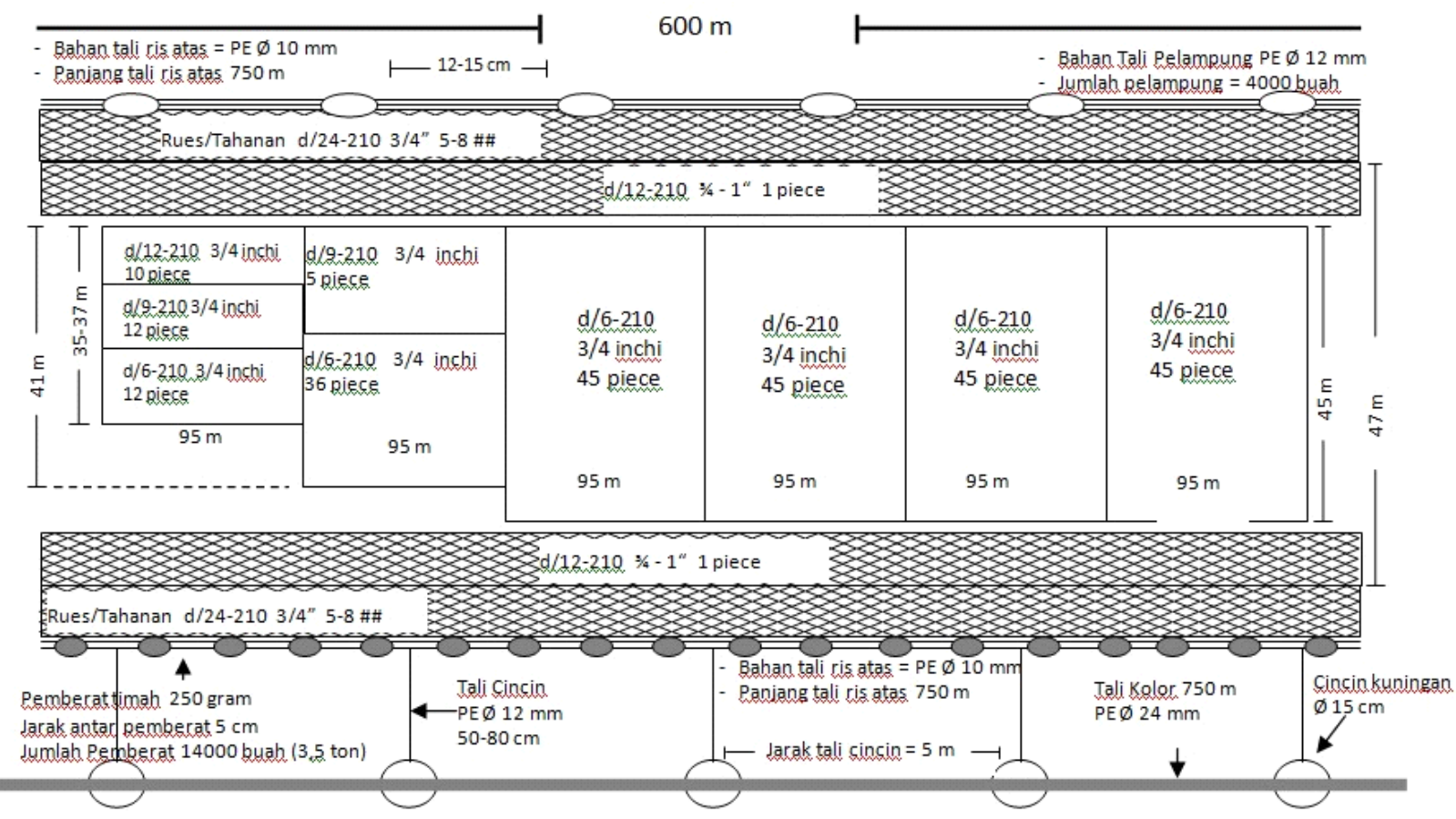

